\title{
加盟館統計による医学図書館評価の試み
}

\section{Preliminary Survey of Medical Libraries in Japan}

\author{
木下 順 一* 土屋久子 光 斎 重 治** \\ 大阪市立大学附属図書館医学部分館
}

\section{I 、はじめに}

図書館を計量的に把握し，評価しようとする試みは， 従来いろいろな面でなされてきた。かつては，その基 準が図書館の大きさ, 即ち物理的な建築面積であり, 蔵書量の絶対数であった。

近年, 公共図書館をはじめとして，利用の拡大が叫 ばれ，貸出の増加が図られた。その結果，図書館の活 動を示す一つの尺度として，貸出冊数が用いられ，そ の蔵書に対する比率として，回転率が論じられるよう になった。

しかし，膨大な蔵書量を誇る大学図書館において， 貸出冊数を蔵書数で除した回転率や，コピーをも含め た館内利用が多数考えられる雑誌等の資料の貸出冊数 の比較では，本当の意味の図書館活動の計量的把握に はならないと考えられる。特に情報化時代に招ける最 近の相互利用の発展からは，他館に対する Document delivery あ図書館活動の大きな要素を占めて おり，まして日本医学図書館協会に加盟する医学図書 館のように，資源共有の理念のもとに，互恵互助の精 神で広く学外の利用者にもサービスを提供することを 建て前とする図書館においては，これらの数字む無視 することはできない。

今回報告する評価の試みは，森耕一氏が公共図書館 の評価に用いた手法"1にヒヒントを得たものであり，毎 年協会が発行する「加盟館統計」から得られる数字を

\footnotetext{
* Jun'ichi KINOSHITA : Medical Library, Osaka City University. 1-4-54 Asahi-machi, Abeno-ku, Osaka 545, Japan.

*** 現 中部大学附属三浦記念図書館
}

（平成元年 3 月 17 日 受理）
加工し，比較することにより，図書館サービスの評価 を計量的に探万うとするあのである。

数字は総て,「第57次日本医学図書館協会加盟館統 計昭和 60 年 4 月〜 61 年 3 月」のものを用い，対象は大 学図書館 (88館) に限定した。

このような「加盟館統計」を用いた分析には今まで に昼馬 ${ }^{2)}$ や河田 ${ }^{3)}$ のあのがあり，医学図書館の統計に 関しては，さきの河田のものを含めた特集 ${ }^{4)}$ 組まれ ているが，今回は基本的な諸元との比較等による図書 館の評価を試みたものである。

\section{II. 評価項目の設定と数值}

図書館活動を測定できるものとして，加盟館統計か ら得られる数字から, 基本的項目として, 面積・開館 時間・年間増加冊数 - 受入雑誌数 - 資料費 - 館員数を 選び，利用に係わる項目として，貸出冊数・複写件数・ 相互利用（貸）件数を選定した。

項目として扱う数值は，下記のようにして求めた。

・面 積 : 分館・分室を含む

- 開館時間 : 1 週間の平均開館時間 $\times$ 年間開館日数

- 年間增加冊数 : 図書館受入分のみ (教室受入分を含 まず）

- 受入 雑 誌 数 : 図書館受入分のみ（教室受入分を含 まず)

- 資 料 費: 図書館分のみ (単行書・雑誌以外の資料 費は除外）

- 管 員 : 専任職員の定員内・定員外の合計

・貸出冊数 : 報告のまま

・複写件数 : 枚数で報告している館については 1 件 8 枚で算出 
表 1. 基本的項目の絶対数によるベスト10

\begin{tabular}{|c|c|c|c|c|c|c|c|c|c|c|c|c|c|c|}
\hline \multirow{2}{*}{$\begin{array}{l}\text { 順 } \\
\text { 位 }\end{array}$} & & \multicolumn{2}{|c|}{ 開 館 時 間 } & \multicolumn{2}{|c|}{ 年間増加冊数 } & \multicolumn{2}{|c|}{ 受入雑 誌 } & \multicolumn{2}{|c|}{ 資 料 費 } & \multicolumn{2}{|l|}{ 館 } & \multicolumn{2}{|c|}{ 利用対象者 } \\
\hline & 館名 & $\left.n^{2}\right)$ & 官名 & 時間 & 館名 & (冊) & 館名 & (䚾) & 館名 & (千P & 館 & 人) & 館名 & （人） \\
\hline 1 & & & & & & & & & 大 & 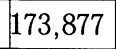 & & 27 & 召和 & 115 \\
\hline & & & & & & & & & 応 & & & & & \\
\hline 3 & L大 & 754 & & & 明 & 256 & 慶应 & 801 & 岡 & 1223 & 囷 & & 百女 & 310 \\
\hline 4 & 大 & 26 & | & & 帝京 & & 九大 & & 東北 & & & & 日矦 & \\
\hline 5 & 笔手 & 859 & 大 & & 金医 & 37 & 岩手 & 23 & 帝京 & 108 & 阪 & 18 & 又大 &, 79 \\
\hline 6 & 北 & 25 & 月山 & & 医 & 8 & 金沢 & 2,245 & 東海 & 104, & 札 & 18 & 材 & 72 \\
\hline 1 & 大 & 13 & 恵 & & 㟒手 & & 東北 & 18 & 日大 & 102 & 九 & 18 & 几大 & 59 \\
\hline 8 & 治 & 828 & 七里 & 9 & 日大 & 19 & 昭和 & 604 & 日松歯 & 100 & \pm & 18 & 䇣田 &, 54 \\
\hline 9 & 医 & 24 & 州 & & 波 & 5 & 日医 & 08 & 岩手 & 94,154 & 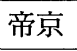 & + & 閪 & 517 \\
\hline 10 & 歯 & 639 & 度応 & & 松歯 & 6,339 & 北里 & 1,973 & 昭和 & 88 & 東 & 17 & E歯 & 4,42 \\
\hline$[x-1$ & - & 2,218 & - & & - & & - & 1,383 & - & 0 & - & & - & \\
\hline & 位 & 1,509 & 9位 & 2,310 & 4位 & 2,925 & 58位 & 1,030 & 68位 & 31,397 & 80位 & 5 & 52位 & 2,41 \\
\hline
\end{tabular}

表 2、利用に係わる項目の絶対数によるベスト10

\begin{tabular}{|c|c|c|c|c|c|c|}
\hline \multirow{2}{*}{$\begin{array}{l}\text { 順 } \\
\text { 位 }\end{array}$} & \multicolumn{2}{|l|}{ 貸 } & \multicolumn{2}{|l|}{ 複 } & \multicolumn{2}{|c|}{ 相互貸借 } \\
\hline & 館名 & (冊) & 館名 & （件） & 館名 & （件） \\
\hline 1 & 東大 & 70,656 & 筑波 & 106,760 & 阪大 & 262,773 \\
\hline 2 & 日大 & 68,355 & 阪大 & 100,092 & 東大 & 164,400 \\
\hline 3 & 京都 & 66,373 & 日医 & 85,380 & 札幌 & 35,132 \\
\hline 4 & 阪大 & 60,956 & 自治 & 84,131 & 兵庫 & 34,58 \\
\hline 5 & 慶応 & 60,392 & 東邦 & 77,795 & 神戸 & 30,983 \\
\hline 6 & 徳島 & 54,141 & 防医 & 64,623 & 慈恵 & 23,73 \\
\hline 7 & 岩手 & 50,077 & 秋田 & 61,704 & 独協 & 22,780 \\
\hline 8 & 東女 & 47,909 & 順天 & 59,875 & 東北 & 21,085 \\
\hline 9 & 山口 & 46,573 & 慶応 & 56,450 & 東医 & 21,051 \\
\hline 10 & 九大 & 42,874 & 富山 & 56,188 & 阪市 & 20,329 \\
\hline 平均 & - & 21,355 & - & 24,015 & - & 11,011 \\
\hline 阪市 & 52位 & 15,214 & 74位 & 3,991 & - & - \\
\hline
\end{tabular}

-相互利用(貸)件数 : 謝絶を含む受付件数

各項目における数值のベスト 10 は表 1 , 表 2 のとおり となった。「表」中における館名は日本医学図書館協 会加盟館統計による。

\section{III. 各項目の算定法と評価法}

各項目の絶対数のみの比較であれば, 大学規模など
によって左右され，正確な評価は得られにくいので， 各項目をサービス対象人員数で除した利用者 1 人当た りの数値を算定してみた。利用に関する項目で「相互 利用 (貸)」件数については, 自館の利用者 1 人当た りの数は意味を持たないので, 館員 1 人当たり, どれ だけの受付件数を処理したかを算定して比較すること にした。また，「サービス対象人員」で「館員」を除 した利用者 1 人当たり何人の館員がサービスに当って いるかの数値をむつけ加えた。

各項目の対象利用者におけるべスト 10 を表 3 , 表 4 にまとめた。

各表のそれぞれの項目で算定された生の数値で評価 することは，項目間の比較や「基本的項目」「利用に 関わる項目」等のグルーピングに数字が細かすぎて不 便な点がある。

そこでさらに, 各項目の平均值を求め, それぞれの 平均值より $20 \%$ 以上高いものを「 5$\rfloor, 10 \%$ 以上 $20 \%$ 未満を「 4 」, 平均値周辺を「3」, 平均値より $10 \%$ 以 下 $20 \%$ 未満低いものを「 2 , 平均值20\%以下のもの を「1」として, 各館の項目ごとに評価点を与え, そ れで一応の評価を試みることにした。

館の記号は M (医科系) と D (歯科系) に大別し， 表に現れた順に適当に番号を付した。各表間の番 号は共通である。特定の館がどの番号に相当する 
表 3. 基本的項目の対利用者数によるベスト10

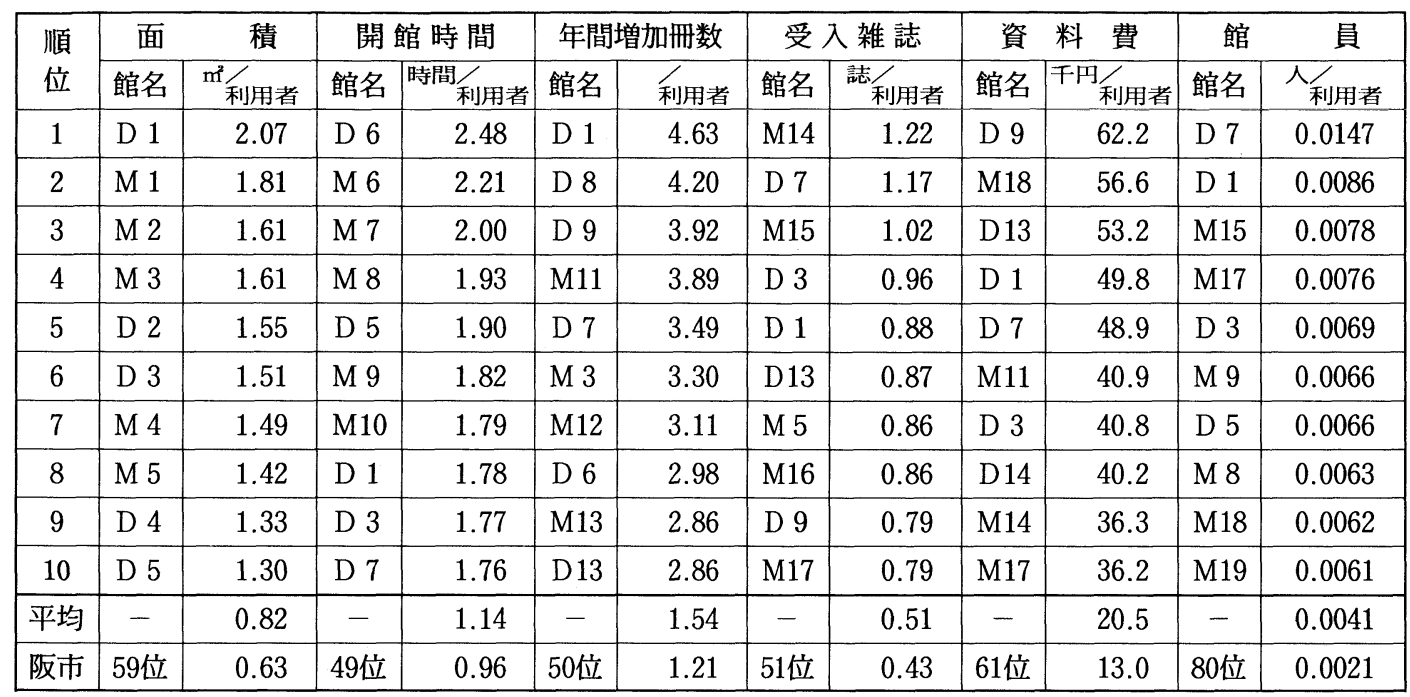

表 4. 利用に係わる項目の対利用者数によるベスト10

\begin{tabular}{|c|c|c|c|c|c|c|}
\hline \multirow{2}{*}{$\begin{array}{l}\text { 順 } \\
\text { 位 } \\
\end{array}$} & \multicolumn{2}{|c|}{ 貸出冊数 } & \multicolumn{2}{|c|}{ 複写 件 数 } & \multicolumn{2}{|c|}{ 相互利用 } \\
\hline & 館名 & 冊利用者 & 館名 & 件 利用者 & 館名 & 件利用者 \\
\hline 1 & M21 & 21.9 & M13 & 46.4 & M14 & 14598.5 \\
\hline 2 & M22 & 20.0 & M 7 & 38.1 & M23 & 11742.9 \\
\hline 3 & M23 & 17.0 & M 3 & 34.0 & 阪市 & 4065.8 \\
\hline 4 & M24 & 16.9 & M 4 & 32.7 & M32 & 3144.1 \\
\hline 5 & M17 & 6.9 & M28 & 25.5 & M26 & 2383.3 \\
\hline 6 & M13 & 15.8 & M29 & 21.8 & M18 & 1951. \\
\hline 7 & M25 & 15.1 & M30 & 20.9 & M33 & 1816.8 \\
\hline 8 & M26 & 14.4 & M14 & 20.9 & M 1 & 1752.3 \\
\hline 9 & M18 & 13.4 & M16 & 19.8 & M34 & 1695.1 \\
\hline 10 & M27 & 12.7 & M31 & 19.1 & M35 & 1540.1 \\
\hline 平均 & - & 7.5 & - & 8.7 & - & 864.0 \\
\hline 阪市 & 49位 & 6.3 & 75位 & 1.7 & 3 位 & 4065.8 \\
\hline
\end{tabular}

かは, 好評価により実名を用いた館以外，読者の 想像に任せる。

\section{IV. 評 価}

表3, 表 4 におけるベスト10に顔を出す館はすべて 評価点は「5」であった。

これを項目ごとに分析してみた。

\section{1. 各項目における評価}

面 積: 歯科系大学がベスト10の半数を占め, 残り は新設医科大学であった。新設の医科大学は日本医学 図書館協会 (以下, 協会とする) 加盟の新しい大学と いうことで, 協会の加盟基準をクリアするために努力 した結果であろう。

開館時間 : 面積と同じく歯科系大学が半数を, そし て国立の新設医科大学が残り半分を占めた。国立の新 設医科大学のこのような状況は文部省の指導が十分行 き届き, 超過勤務手当等の予算化が行われ，保障され ているためであろうか。

年間増加冊数 : この項目においても歯科系大学が半 数以上を占めている。上位 10 館の学生 1 人当たりの平 均増加冊数は3.5冊であった。1 位の北歯（D 1 ）は 全平均増加冊数の 3 倍むあり, 目を見張るものである。

受入雑誌: やはり外国雑誌センタ一館である阪大 （M14）がトップであるが，この項目においても歯科 系大学が半数を占めている。いろいろな面で充実が遅 れている公立大学の中で福島（M15）がここで 3 位 であることは注目に価するものであろう。

資料費 : ここでも歯科系大学の図書館に対する積極 さと, 経済的な余裕が窺える。一方, 福岡 (M18)・ 東海 (M19) ・慶応 (M17) の私学の図書館と, 外国 雑誌センター館の阪大（M14）が健闘しているとい 
えよう。

館 員 : 上位 10 館の図書館員 1 人当たりの利用対象 者の平均は 137.7 人で, 全加盟館平均の約半分で当館 とは3.5倍の違いがある。この項目にあってあ歯科系 大学が上位にいるが, 島根 (M 9) ・滋賀 (M 8$)$ ・旭 川（M19）といった国立の新設医科大学が健闘して いる。このことは, 比較的利用対象（教職員・学生） が少ないのにかかわらず，一定数の職員が確保されて いる国立の余裕を見る思いがする。また，開館時間と 同様, 国（文部省）の図書館に対する積極的な政策の あらわれであろうか。

貸出冊数: 基礎的項目之打って代わって, 歯科系大 学がベスト10に進出することがなく, 医科系図書館で 占められている。

複写件数 : 複写は貸出と相関関係にあると考えられ, 同等のウエイトを持っているといえよう。歴史の新し い図書館が台頭している。

相互利用：阪大（M14）と東大（M23）が群を抜 き, 1 ・2 位を占めている。これは, 外国雑誌センター 館として, 或いは歴史ある図書館としての務めからこ のような結果が生まれたのであろう。また，歯科系の 進出が見られないのは, 所蔵資料の違いが大きく左右 しているからであろうか。

以上，基本的項目，利用に係わる項目のそれぞれに

\section{表 5．基本項目評価点}

\begin{tabular}{|c|c|c|}
\hline 順位 & 館名 & 評価 \\
\hline 1 & D 1 & 30 \\
\hline 1 & D 3 & 30 \\
\hline 1 & D 7 & 30 \\
\hline 4 & M 3 & 27 \\
\hline 5 & M28 & 26 \\
\hline 5 & M18 & 26 \\
\hline 5 & D 5 & 26 \\
\hline 8 & M15 & 25 \\
\hline 8 & M 5 & 25 \\
\hline 8 & D 9 & 25 \\
\hline 70 & 阪市 & 13 \\
\hline
\end{tabular}

表 6 . 利用項目評価点

\begin{tabular}{|c|c|c|}
\hline 順位 & 館名 & 合計 \\
\hline 1 & M 17 & 15 \\
\hline 1 & M 14 & 15 \\
\hline 3 & M 28 & 13 \\
\hline 4 & M 27 & 12 \\
\hline 4 & M 13 & 12 \\
\hline 4 & M 16 & 12 \\
\hline 4 & M 35 & 12 \\
\hline 8 & M 36 & 11 \\
\hline 8 & M 24 & 11 \\
\hline 8 & M 23 & 11 \\
\hline 8 & M 36 & 11 \\
\hline 8 & M 34 & 11 \\
\hline 8 & M 29 & 11 \\
\hline 8 & M 22 & 11 \\
\hline 8 & M 26 & 11 \\
\hline 23 & 阪市 & 9 \\
\hline
\end{tabular}

ついて見てきたが，まとめてみると，基本的な項目の 得点（満点30点）のベスト10は, 表 5 のようになり, 利用に関する項目（満点15点）では表 6 となって, 富 山（M28）を除いては内容が一変する。基本的項目 で満点となったものはすべて歯科大学の図書館であり, 他にも高い得点の館が 2 館あって, 全体の比率からいっ ても，この項目における歯科系大学図書館の充実が目 立っている。歯科系大学図書館は協会加盟が比較的新 しく, 協会の加盟基準をクリアし, 古い館に追いつけ 追いこせと，資料をむ含めた設備面に相当の投資を行っ ている事がうかがえる。また，医科系に比べて，看護 専門学校や，医療技術短大等を持たないところが多く， 分母となる利用者数が少ないため，1 人当たりの数字 を良くしているのかもしれない。それにしても，新設 医大の富山（M28）と公立の福島（M15）の健闘は光っ ている。しかし, 目を利用に関する項目に転じると, 上位15館（同得点のところがあるので，8位タイまで 15館となる）の内から表 5 におけるべスト10は, 富山 （M28）以外総て姿を消してしまう。このことは，基 本的項目に当たる部分に力を入れることは大切ではあ るが，それだけでは利用者（協同体に属する他館の利 用者をあ含めて）を十分満足させることはできないと いうことを物語っているように思われる。以上の結果 をレーダーチャートにしてみると, 図 1 と図 2 のよう になる。

\section{表 7. 総 合 評 価}

\begin{tabular}{|c|c|c|c|c|}
\hline 順位 & 館名 & 基礎 & 利用 & 総計 \\
\hline 1 & M28 & 26 & 13 & 39 \\
\hline 2 & D 1 & 30 & 8 & 38 \\
\hline 2 & M17 & 23 & 15 & 38 \\
\hline 2 & M14 & 23 & 15 & 38 \\
\hline 5 & D 3 & 30 & 7 & 37 \\
\hline 5 & D 7 & 30 & 7 & 37 \\
\hline 7 & M 5 & 25 & 11 & 36 \\
\hline 8 & M18 & 26 & 9 & 35 \\
\hline 8 & M 3 & 27 & 8 & 35 \\
\hline 10 & M 4 & 24 & 9 & 33 \\
\hline 68 & 阪市 & 13 & 9 & 22 \\
\hline
\end{tabular}




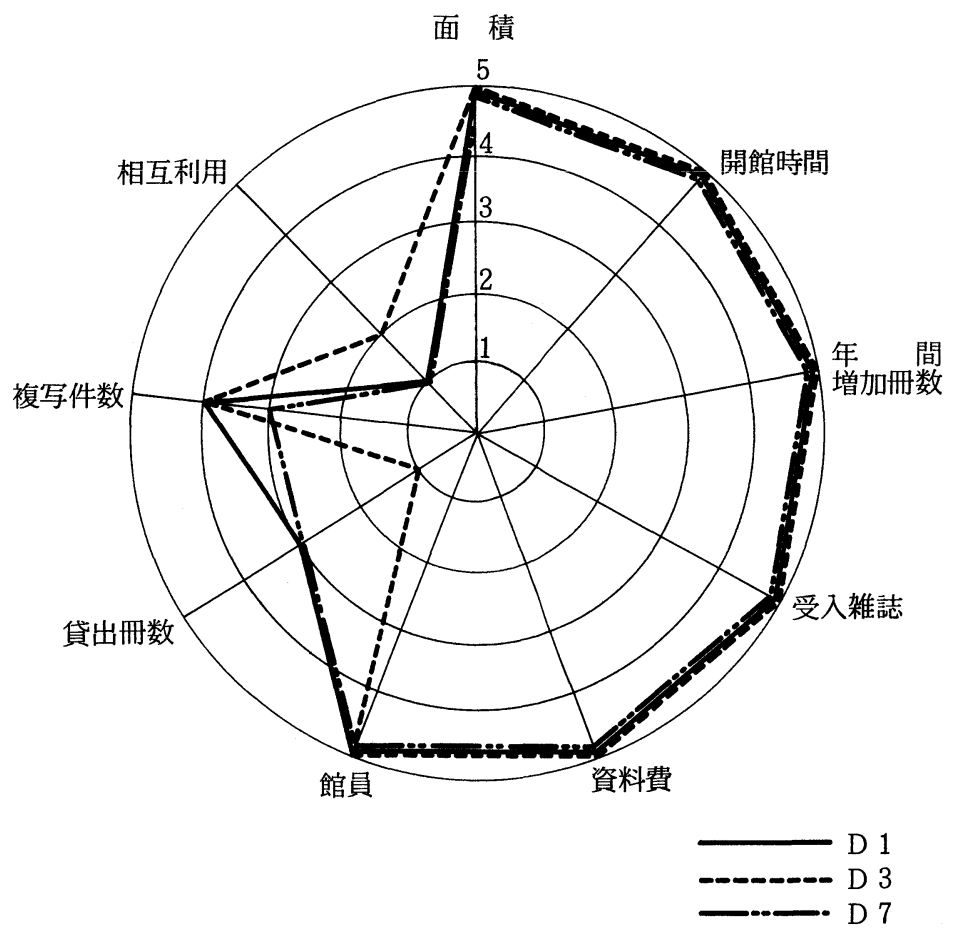

図1. 総 合 評 価

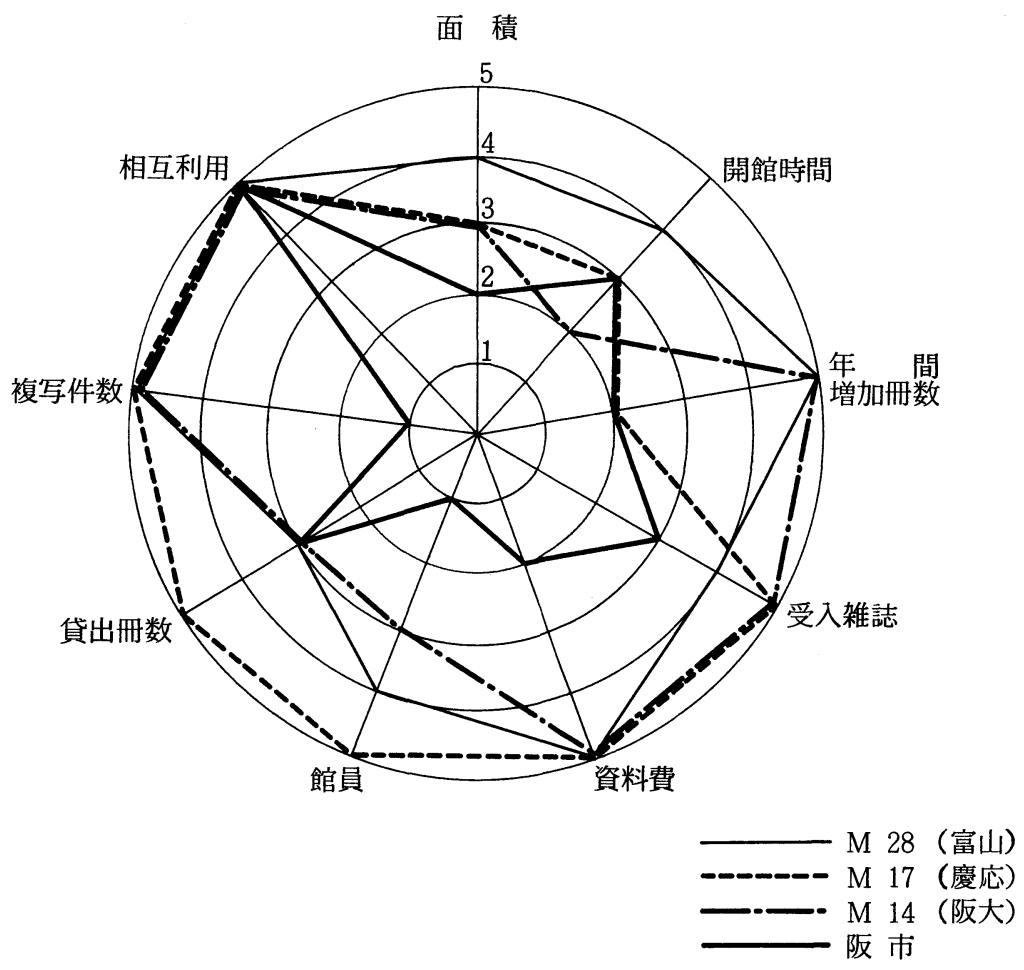

図2. 総 合 評 価 
図 1 は, 基本的項目のトップ 3 館の点数を表したも のでその片寄り具合が一目瞭然である。

図 2 は, 利用に係わる項目のトップ 3 館と当館とを 比較したものである。富山（M28）が比較的安定し た型をしており，総合評価（表 7 ）で 1 位となること あうなずけるところである。慶応（M17），阪大（M 14）あ部分的に落ち込むところああるが，さすがに全 体としてはほぼ安定している。

ところが当館は非常にアンバランス型をしており， 是正すべき点が多々みられる。小さな数字なりに安定 （円に近い）していた方がよいのか，ひとつでも突出 している点を評価すべきなのか，判断に苦しむところ である。

利用に関する項目の得点には, 相互利用の点数が大 きくひびいているようであり，相互利用にむいている 資料の所蔵が少ないと思われる歯科系の点数が低くなっ て, 歯科系の図書館にとっては不利な評価とはなるが, 客観的にみても，ここではさすがと思われる館が多く 浮び上がっており，あながち乱暴な評価ではないよう に思われる。

\section{V. おわりに}

図書館活動の計量的把握による評価は大变難しく, 参考業務等における質的評価に及ぼすことはできない し，またこここに選定した 9 項目だけで総てを判断す ることは危険である。しかし質的判断の基準がなく， 量的な判断にしても, 絶対数の比較だけでは正確な評 価につながらないと考え，今回，以上のような試みを してみた。

現在のところまだ確実なことをいえる段階ではない が，図書館は利用されてはじめてその価值を発揮する のはいうまでもないことなので，やはり利用に関する 項目において, 高い評点を得る必要がある。今回は平 均点をべースにした相対評価であるが，将来何等かの
科学的根拠が得られるならば，それをもとにした絶対 評価を試みたいと思っている。

また，基本的項目の充実が，直接利用に結びついて いない点は極めて残念であるが，さりとてこれらの諸 点をおろそかにすることはできない。何故なら，これ らの点がおろそかにされているところは，更に悪い結 果を生むことが予測されるからである。今ひとついえ ることは，相互協力に熱心なところは館内利用も高く， 総体的に高い評価が得られていることである。日本医 学図書館協会の理念と伝統が息づいているところであ ろうか。

最後に統計数字の提出に際して, 求められている数 字が何であるかを十分把握する必要があるように思わ れる。提出される数字が不明瞭であれば，正確な分析 はできないし，あやまった結論を導く恐れがある。

今後機会があれば, 更に詳しい分析と評価を行い, 外国との比較なども試みて, 我が国の医学図書館の標 準値を探りたいと思っている。

なお，この研究には昭和62年度の協会の研究助成を 受けた。記して感謝の意を表したい。

\section{参考文献}

1) 森 耕一 図書館評価の一試案. 図書館雑誌 $1986 ; 80$ (8) : 476-8.

2 ) 昼馬逸郎 加盟館統計からみた国立大学医学図書 館の実態側面. 医学図書館 $1980 ； 27(2): 73-$ 81.

3 ) 河田政雄 統計からみた日本の医学図書館におけ る運営形態のパターン一昭和 40 年日本医学図 書館協会加盟館統計加 一一. 医学図書館 1967 ; $14(3)$ : $273-97$.

4 ) 北川敏男他 特集 : 医学図書館統計. 医学図書館 $1967 ; 14(3): 189-272$. 